\section{A Direct Entry to Organic Chemistry}

By Prof. John Read. (Home Study Books, No. 6.) Pp. xiii+268. (London: Methuen and Co., Ltd., 1948.) 4s. 6d. net.

THE schoolboy's Woll-known observation that 1 "Read's hooks GHe so readable" is most surely applicable herefifnywere. This self-contained little book will apparl alike to the intelligent layman and also tppthe who wish to begin the study of organic clemis $y^{\prime}$ and are in search of a general survey of the Nsubject before embarking upon the standard text-books. Indeed, the title "A Direct Entry to Organic Chemistry" is very apt, as the book leads one quickly, easily and with the minimum of preliminaries right into the subject. Conventional fundamental ideas about atoms, molecules, electro. valent and covalent linkages, and isomerism are dealt with clearly and simply. Subjects discussed from an attractive descriptive angle include fats, carbo. hydrates, proteins and coal-tar products; and brief simple references are made to such topics as penicillin and chemotherapy. Quite apart from any information which the general reader may readily pick up from the book, it is also obvious that Prof. Read has interwoven in its pages something of the philosophy and spirit of chemistry which have made some of his earlier historical sketches so much alive. It is fitting that the book should have been the subject of the award of the "Premio Europeo Cortina Prize" of a million lire $(£ 500)$ given by the Italian journal Ulisse for the best recently published popular scientific $\begin{array}{ll}\text { work. } 3 \text { B. C. SAUNDERS } & \end{array}$ Un naturaliste en Cote d'Ivoire

Par Renaud Paulian. (Fes livres de nature, 74.) Pp. 217. (Paris: Editiptos Stock, 1949.) 270 francs 7 HIS small booh fives in a semi-popular style an account/ of he animal and, to a less degree, plant life in a trobical West African forest region. It is mainly chcerned with the forest reserve of Banco, some $8 \mathrm{kth}$ from Abidjan in the French Colony of the Ivow Coast. Much of the forest is secondary; butfome more or less primary forest was visited. It stated that forest reconstituted in place of secondary forest has a fauna comparable to that of a true primary forest but that floristically the constitution remains difierent. A majority of pages are devoted to insects, and the chapters on ants and termites are particularly interesting. Studies of organisms in a tree canopy were made by means of observation posts established up to $37 \mathrm{~m}$. in a tree of Parinarium tenuifolium. The nocturnal life of organisms in the forest canopy proved as regular as diurnal life. The book is illustrated by forty-seven clear text figures, mostly of animals and plants, but has no index. Hff W. B.T.

Les fondements lde la geographie humaine

Par Prof. Max Sorre. Tome 2: Les fondements techniques, Premiere pqrtie: Les techniques de la vie sociale, les techn flues et la geographie de l'energie, la conqueteple l'espace. Pp. 608. (Paris : Armand Coling 19.5 1100 francs.

T YNFORT HAf fLY, only half of this work on social geogr thy by Prof. Max Sorre, of the Sgabonnenas yet appeared, and the text now before uf is not hecessarily fully representative of the whole. uf off t volume was "Les Fondements biologiques"; of the second volume the work now before us forms Part 1, but Part 2, "Les Techniques de Production", has not yet been published, while Vol. 3, "L'Habitat", has also yet to appear. The third volume will con. centrate most closely on the factor of environment and is thus likely to be the most useful contribution of all to the geographer.

The work is very ambitious, and indeed, from the study of Vol. 2, Part 1 alone, it is doubtful if the reviewer has had access to a sufficient proportion of the entire work to pass a fair verdict on its range and quality. This difficulty is the more obvious because of the minuteness of the detail by which Prof. Sorre illustrates his argument in a survey of the evolution of transportation and of the routes of commerce; for it is on the subject of the evolving geography of routes that Sorre is here primarily concerned. Such a subject holds a nuclear position in "la geographie humaine" which, the reviewer believel, should preferably be translated into English as 'social' not 'human' geography. Sorre's debt to the inspiration derived from Vidal de la Blache, the founder of the most distinguished French school of geographical philosophy, is recognized on almost every page and not only in the extensive bibliography.

\section{Population Analysis}

W. Fitzgerald

By T. Lynn Smith. (MeGraw-Hill Publications in Sociology.) Pp. xiii +421. (New York and London: McGraw-Hill Book Co., fnc., 1948.) 27s.

DOPULATION analys in any serious sense, is here confined to the United States, for which is made the proporam of leadership in demographic studies. Vjrtual f f triction of inquiry to the United States in respect of density of population, composfign 16 racial origins, fertility, mortality, migra. tio Nfc., treated in successive chapters, is at once observod by the range of the many cartogramsreminiscent of the excellent illustrations in the U.S.A. Census Reports-and, quite frankly, the author writes with an American audience in mind. Although this is suggested in the preface, it might have appeared also in the title, now too comprehensive. Probably to American undergraduates the geographical limitation will not seem important, though for purposes of balance and perspective it seems urgent to the reviewer that particularly the younger students of population in the modern world should learn to avoid too parochial an outlook and too little attention to the eastern hemisphere, where the greater part of the population of the world resides.

\section{British Herbs}

W. Fitzgerald

By Florence Ranson. (Pelican Books, A.183. Pp. $203+16$ plates. (Harmondsworth : Penguin Books, Ltd., 1949.) 1s. $6 d$.

THIS little bof f entains an account of British 1 herbs and their uses, with useful information on their histd finints on herb gathering and drying, commercial herb growing and marketing. The plants are drranged alphabetically by their common names, fol owed by a chapter on the herb garden, dealing with the aspect of such a garden, its cultivation and arrangement. The book is well illustrated by line drawings and several excellent photographs. A list of books for further study and an index of common names is provided, but it seems a pity that the botanical names of the plants dealt with were not included in the index. There is much in this volume to attract the attention of those interested in herbs, and it forms a useful addition to the well-known series of Pelican books. 